\title{
Food resource partitioning among species of Astyanax (Characiformes: Characidae) in the Lower Iguaçu River and tributaries, Brazil
}

\author{
Suelen F. R. Pini ${ }^{1}$, Milza C. F. Abelha ${ }^{2}$, Elaine A. L. Kashiwaqui ${ }^{2}$, Rosilene L. Delariva ${ }^{3}$, \\ Sergio Makrakis ${ }^{1}$ and Maristela C. Makrakis ${ }^{1}$
}

Resource partitioning allows for interspecific coexistence and is frequently reported for similar species. Here, we predicted the existence of resource partitioning among species of Astyanax that co-occur in the Low Iguaçu River and tributaries in Brazil. A total of 848 stomachs of five species of Astyanax were analyzed. Algae, terrestrial plant and fruit/seed were the most consumed resources. Astyanax bifasciatus and A. dissimilis had predominantly herbivorous diets, A. gymnodontus and A. lacustris were omnivorous, and A. minor was mainly algivorous. Permutational analysis of variance showed the species had different diets, and similarity percentage analysis indicated that fruit/seed and terrestrial plant contributed the most to this differentiation. A paired comparison indicated that the trophic breadth of A. gymnodontus differed from that of other species. The food overlap was low for $55 \%$ of Astyanax pairs. These results showed alignment with the niche theory, in which differentiation in the use of food resources facilitates the coexistence of species and minimizes competition. These adjustments to coexistence become relevant in the context of endemic species in a highly isolated basin under intense threat (dams, species introduction, deforestation, and pollution) as is the case for the Iguaçu River basin.

Keywords: Coexistence, Congeneric species, Diet, Diet overlap, Niche theory.

O particionamento de recursos permite a coexistência interespecífica e é frequentemente relatado para espécies semelhantes. Predizemos a existência de partição de recursos entre espécies de Astyanax que co-ocorrem no baixo rio Iguaçu. O total de 848 estômagos de cinco espécies de Astyanax foi analisado. Algas, plantas terrestres e frutos/sementes foram os recursos mais consumidos. Astyanax bifasciatus e A. dissimilis apresentaram dietas predominantemente herbívoras, A. gymnodontus e $A$. lacustris foram onívoras e A. minor foi principalmente algívora. As espécies apresentaram diferentes dietas (PERMANOVA) e a análise SIMPER indicou que frutos/sementes e plantas terrestres tiveram maior contribuição para esta diferenciação. A comparação pareada mostrou que a amplitude trófica de A. gymnodontus diferiu das outras espécies. A sobreposição alimentar foi baixa para 55\% dos pares de Astyanax. Nossos resultados mostraram-se alinhados com a teoria de nicho, em que a diferenciação no uso de recursos alimentares facilita a coexistência de espécies e minimiza a competição. Estes ajustes para coexistência tornam-se relevantes no contexto de espécies endêmicas em uma bacia altamente isolada e sob intensa ameaça (barramentos, introdução de espécies, desmatamento e poluição), como é o caso da bacia do rio Iguaçu.

Palavras-chave: Coexistência, Dieta, Espécies congêneres, Sobreposição de dieta, Teoria de nicho.

\section{Introduction}

Unlike terrestrial species or those with aerial or winddispersed life stages, species confined to freshwater environments generally cannot disperse from one catchment to another, unless corridors of aquatic habitats exist to connect them (Abell et al., 2008). Thus, the connections and disconnections between adjacent river basins have long been recognized as essential for the diversification of freshwater fish in the Americas (Buckup, 2011). In contrast, tectonic movements have in some cases established barriers to dispersal (vicariance) between adjacent river basins,

\footnotetext{
${ }^{1}$ Grupo de Pesquisa em Tecnologia em Ecohidráulica e Conservação de Recursos Pesqueiros e Hídricos (GETECH), Programa de Pós-graduação em Engenharia de Pesca, Universidade Estadual do Oeste do Paraná (UNIOESTE), Rua da Faculdade, 645, Jardim La Salle, 85903-000 Toledo, PR, Brazil. (SFRP) suelen.pini@hotmail.com (corresponding author), @https://orcid.org/0000-00022897-1082; (SM) sergio.makrakis@unioeste.br, @https://orcid.org/0000-0002-7868-9034; (MCM) maristela.makrakis@unioeste.br, (Chttps://orcid.org/0000-0001-7539-9659

${ }^{2}$ Grupo de Estudos em Ciências Ambientais e Educação (GEAMBE), Universidade Estadual de Mato Grosso do Sul (UEMS), BR 163, Km 20.7, 79980-000 Mundo Novo, MS, Brazil. (MCFA) milza@uems.br, @https://orcid.org/0000-0003-0942-7695; (EALK) elainealk@uems.br, ○https://orcid.org/0000-0002-4493-2980

${ }^{3}$ Programa de Pós-Graduação em Conservação e Manejo de Recursos Naturais, Universidade Estadual do Oeste do Paraná (UNIOESTE), Rua Universitária, 2069, Jardim Universitário, 85819-110 Cascavel, PR, Brazil. rosilene.delariva@unioeste.br, (Chttps://orcid.org/0000-0002-6489-2437
} 
allowing for further speciation and giving rise to endemic fish fauna (Cox et al., 1980; Ricklefs, Schluter, 1993; Albert et al., 2011). The Iguaçu River, a left-bank tributary of the Paraná River in Brazil, has been isolated from the main Paraná valley for approximately 22 million years by a geological lift, which gave rise to the Iguaçu Waterfalls (about $70 \mathrm{~m}$ in height; Maack, 1981). The geographic isolation promoted by this natural barrier has led to the occurrence of many endemic species, which represent more than $50 \%$ of the fish species in the Iguaçu River basin (Baumgartner et al., 2012). Threats to the integrity of this fish fauna diversity (dams, species introduction, deforestation, and pollution) (Baumgartner et al., 2012), coupled with the high endemism, were recognized by Abell et al. (2008), who included this basin as one of the 426 global freshwater ecoregions requiring urgent conservation planning efforts.

In this basin, Astyanax Baird, Girard 1854 stands out for its richness (Pavanelli, Oliveira, 2009), with 11 described species, of which 10 are endemic (Baumgartner et al., 2012). The occurrence of a large number of congeneric species living in sympatry raises a central ecological question, which is to understand how morpho-physiologically similar species minimize competition for resources (Chesson, 2000; Kylafis, Loreau, 2011; Juncos et al., 2015). According to the niche theory, when sympatric species overlap in the use of resources along one dimension, they must differentiate in another resource in order to coexist (Hutchinson, 1957). Species differ mainly in the use of habitat, food, and time
(Schoener, 1974, Wiens et al., 2010; Wang et al., 2015). This differentiation is called resource partitioning (Schoener, 1974) and enables interspecific coexistence (Ross, 1986). Moreover, resource partitioning is widely reported for congeners (Barreto, Aranha, 2006; Neves et al., 2018).

In this context, our study was guided by the following question: Is the coexistence of Astyanax species in the Iguaçu River basin favored by food resource partitioning? We predict that Astyanax species of the Low Iguaçu River consume different resources, presenting low food overlap. Thus, the aims of this study were to i) evaluate the food items used by Astyanax species that co-occur in the Low Iguaçu River; ii) investigate possible differences in the consumption of food resources and in the niche breadth; and iii) infer the degree of overlap among species.

\section{Material and Methods}

The Iguaçu River rises in the Serra do Mar and flows through a geological fault throughout Paraná State (Maack, 1981). The hydrographic basin covers the Paraná and the Santa Catarina states in Brazil and the Misiones region in Argentina (Dalla Corte et al., 2015). The study area comprised the Low Iguaçu River and its main tributaries in the stretch between the Salto Caxias dam and the Santo Antônio River mouth (Iguaçu National Park), where 25 sampling sites were established (the first sampling site: $25^{\circ} 35^{\prime} 17.04^{\prime \prime} \mathrm{S}-53^{\circ} 29^{\prime} 56.58^{\prime \prime} \mathrm{W}$; the last sampling site: $25^{\circ} 35^{\prime} 17.16^{\prime \prime}$ S-5359'25.20”W; Fig. 1).

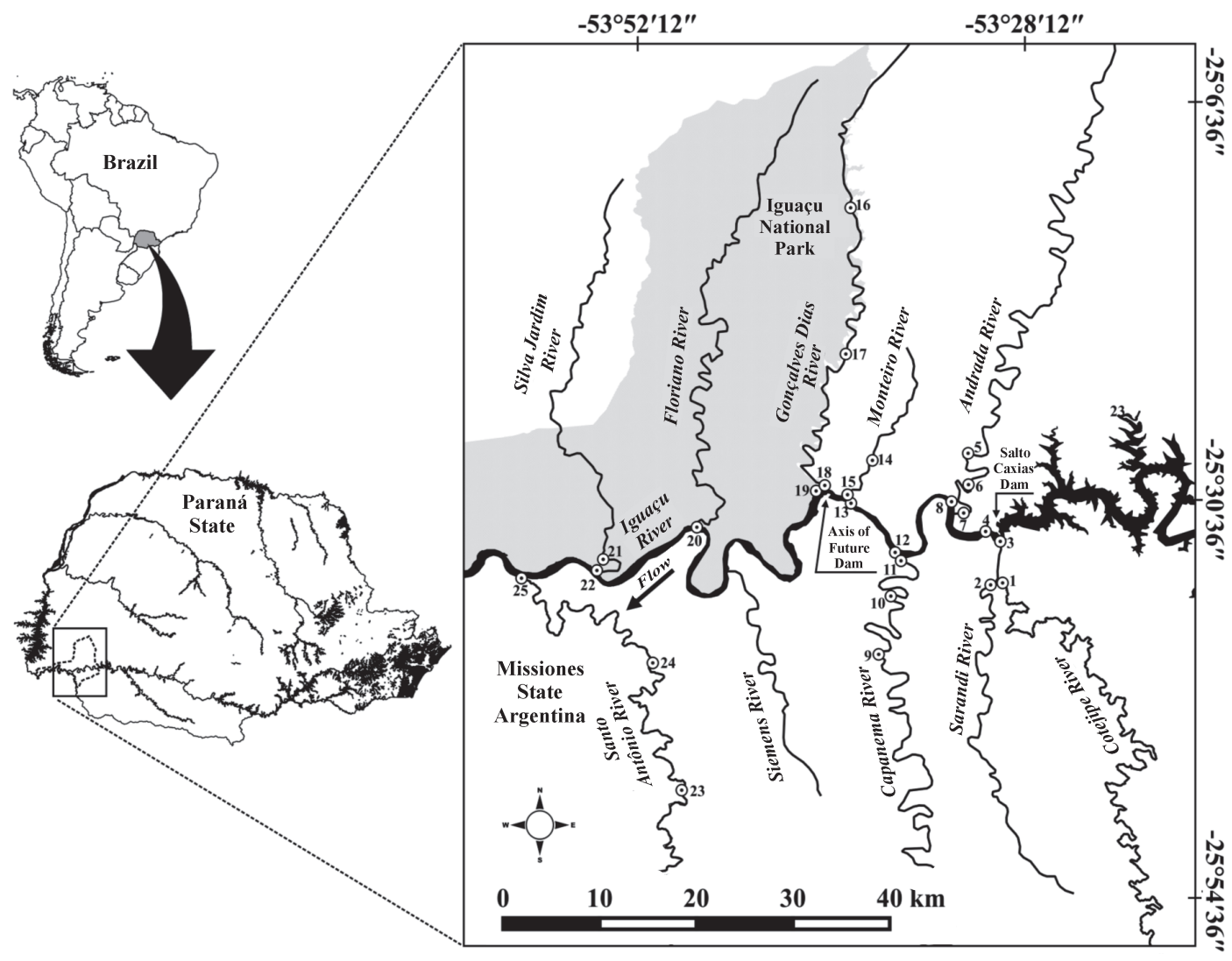

Fig.1. Study area showing the sampling sites (numbers 1 to 25) in the Lower Iguaçu River and tributaries in Brazil. 
Fish were collected monthly from September 2013 to August 2014, using gill nets (2.5-14.0 cm mesh) exposed for $24 \mathrm{~h}$ and inspected every six hours, as well as electrofishing in the morning. Caught fish were euthanized with $250 \mathrm{mg} / \mathrm{L}$ benzocaine [State University of Western Paraná (UNIOESTE) Ethics Committee-Protocol 62/09] and later fixed in $10 \%$ neutralized formaldehyde.

Fish were identified according to Garavello, Sampaio (2010) and Baumgartner et al. (2012), measured (total and standard length), weighed (g), eviscerated, and the stomachs were collected. All the analyzed individuals were considered adults based on macroscopic evaluation of gonadal development. Voucher specimens were deposited in the fish collection of the Zoology Museum/ State University of Londrina (MZUEL) (Tab. 1).

Stomach contents were analyzed using optical and stereo microscopes. The items were quantified according to the volumetric method (volume percentage of each item in relation to the total volume of the stomach contents) (Hyslop, 1980). The volume of each food item was determined using graduated test tubes; for volumes lower than $0.1 \mathrm{~mL}$, a counting chamber was used (Hellawell, Abel, 1971). Food items were identified according to Bicudo, Bicudo (1970) for algae and McCafferty (1981), Borror, Delong (1988), and Mugnai et al. (2010) for invertebrates.

To identify possible differences among the diets of Astyanax species, a permutational analysis of variance (PERMANOVA, Bray-Curtis index) with 9999 permutations was applied to the volume matrix of food items. The data were transformed using the square root to reduce asymmetry and satisfy the premise of homogeneity. When significant differences were detected, pairwise tests using the pseudo $t$-statistic were applied to determine which species showed different diets. The food items that most contributed to distinguish the species pairs were verified using similarity percentage (SIMPER) analysis (Clarke, 1993).

Interspecific differences in diet breadth were evaluated by permutational multivariate analysis of dispersion (PERMDISP) (Anderson, 2006). This analysis was used to measure the distance from the centroid of a group defined a priori, in this case the species, and is calculated by principal co-ordinates analysis (PCoA). Calculation of the centroid of the group was performed using BrayCurtis dissimilarity index values to compare the average dissimilarity among the $n$ individual observations within the group. In this case, the mean distances of the samples in relation to the group mean (centroid) correspond to the niche breadth. In order to test the null hypothesis that the niche breadth did not differ among species, $F$-statistics were calculated using the Monte Carlo method with 9999 randomizations. The pairwise comparison by Tukey's honestly significant difference method was used to indicate differences in the interspecific variability of individuals of each species.
The diet overlap per sample was calculated based on the volume matrix of food items for each pair of Astyanax species at each site and month of collection using the Pianka index (Pianka, 1973) described by the following equation:

$$
O_{j k}=\frac{\sum_{i}^{n} P_{i j} \times P_{j k}}{\sqrt{\sum_{i}^{n} P_{i j} \times \sum_{i}^{n} P_{i k 2}}},
$$

where,

$O j k=$ Pianka niche overlap between species $j$ and $k$;

$P i j=$ proportion of food resource $i$ in the diet of species $j$;

$P i k=$ proportion of food resource $i$ in the diet of species $k$; $n=$ total number of food resources.

The Pianka index ranges from 0 to 1 and indicates low $(0.00-0.39)$, intermediate $(0.40-0.60)$, or high overlap (0.60-1.00), where high overlap values may be indicative of competition or resource partitioning (modified from Grossman, 1986; Novakowski et al., 2008). The overlap index values were transformed to a percentage, ranging from 0 to 100 .

The PERMANOVA and SIMPER analyses were calculated using PRIMER v.6 (Clarke, 1993; Clarke, Gorley, 2006). The PERMIDISP was performed with R (Oksanen et al., 2009; R Development Core Team, 2017). The food overlap analysis was performed using EcoSim 7.0 (Gotelli, Entsminger, 2010). The level of significance in all analyses was 0.05 .

\section{Results}

We analyzed 848 stomachs belonging to five species (Tab. 1): Astyanax bifasciatus Garavello, Sampaio, 2010; Astyanax dissimilis Garavello, Sampaio, 2010; Astyanax gymnodontus (Eigenmann, 1911); Astyanax minor Garavello, Sampaio, 2010; and Astyanax lacustris (Lütken, 1875). The first four species are endemic to the Iguaçu River basin, while A. lacustris is distributed throughout the basin of the Upper Paraná River.

We identified 40 food items consumed by the species that, according to their origin, were classified as allochthonous, autochthonous, and undetermined (Tab. 1). The food items were grouped into 10 categories: terrestrial plant, fruit/seed, terrestrial insect, terrestrial invertebrate, algae, aquatic plant, aquatic insect, fish, aquatic invertebrate, and detritus (Tab. 1).

Algae, terrestrial plant, fruit/seed, and detritus were the most consumed resources. Astyanax bifasciatus and A. gymnodontus foraged on $82.5 \%$ and $72.5 \%$ (33 and 29 items) of the 40 identified items, respectively. Astyanax lacustris and A. minor ingested 24 different food resources, and $A$. dissimilis consumed approximately $60 \%$ of the listed food items (23 out of 40) (Tab. 1).

Items of allochthonous and autochthonous origin appeared in different proportions in the diets of the fish species (Fig. 2). Allochthonous resources (fruit/seed) were predominant in the diet of A. lacustris (Tab. 1). On the other hand, autochthonous resources (algae) dominated the diet of $A$. minor (Fig. 2). The other species consumed similar proportions of both sources (Fig. 2). 
Food resource partitioning among Astyanax species

Tab. 1. Volumetric percentage $(\mathrm{mL})$ of food items consumed by five species of Astyanax and their niche breadth in the Lower Iguaçu River and tributaries in Brazil. $\mathrm{L}=$ larvae; $\mathrm{P}=$ pupae; $\mathrm{A}=$ adult.

\begin{tabular}{|c|c|c|c|c|c|}
\hline Species & A. bifasciatus & A. dissimilis & A. gymnodontus & A. lacustris & A. minor \\
\hline Number of stomachs & 402 & 54 & 153 & 129 & 110 \\
\hline Diet breadth & 0.63 & 0.60 & 0.65 & 0.62 & 0.61 \\
\hline Voucher specimens & MZUEL16267 & MZUEL16339 & MZUEL16353 & MZUEL16359 & MZUEL16346 \\
\hline \multicolumn{6}{|l|}{ ALLOCHTHONOUS } \\
\hline \multicolumn{6}{|l|}{ Terrestrial plant } \\
\hline Terrestrial insect & 2.18 & 12.09 & 8.06 & 15.68 & 4.21 \\
\hline Coleoptera A & 0.48 & 1.49 & 2.52 & 11.72 & 0.89 \\
\hline Diptera A & 0.07 & & 0.01 & 0.03 & \\
\hline Hymenoptera A & 1.10 & 9.04 & 4.34 & 1.11 & 2.93 \\
\hline Isoptera A & 0.01 & 0.34 & & & 0.02 \\
\hline Oligochaeta & 0.19 & 5.98 & 0.19 & 1.98 & \\
\hline \multicolumn{6}{|l|}{ AUTOCHTHONOUS } \\
\hline Algae & 28.96 & 41.36 & 11.07 & 6.42 & 55.55 \\
\hline Bacillariophyta & 0.39 & 0.01 & 0.03 & & 3.17 \\
\hline Chlorophyceae & & & & & 0.85 \\
\hline Cyanophyceae & 2.41 & & 0.14 & 2.89 & \\
\hline Oedogoniophyceae (Oedogonium) & 3.24 & 1.63 & 4.14 & & 5.68 \\
\hline Rhodophyceae (Audouinellaceae) & 0.85 & 1.58 & 0.47 & & 0.33 \\
\hline Rhodophyceae (Compsopogonaceae, Compsopogon caeruleus) & 22.03 & 38.13 & 6.29 & 3.53 & 44.54 \\
\hline Zygnemaphyceae & $<0.01$ & & & & 0.96 \\
\hline Zygnemaphyceae (Spirogyra) & $<0.01$ & & & & \\
\hline Hemiptera A & 0.17 & 0.10 & 0.27 & 0.09 & \\
\hline Lepidoptera L & 0.09 & 0.21 & 0.04 & & 1.19 \\
\hline Lepidoptera $\mathrm{P}$ & $<0.01$ & & & & \\
\hline Odonata A & 0.03 & 0.17 & 0.06 & 1.07 & 0.85 \\
\hline Plecoptera A & 0.02 & & & 0.03 & \\
\hline Simulidae L & $<0.01$ & & & & \\
\hline Trichoptera L & 0.13 & 1.09 & 0.03 & $<0.01$ & 0.01 \\
\hline Fragments of aquatic insects & 0.31 & 0.91 & 0.16 & 0.60 & 1.45 \\
\hline Fish & $<0.01$ & & 10.86 & 0.67 & \\
\hline Scale & $<0.01$ & & 0.06 & 0.67 & \\
\hline Fragments of fish & & & 10.80 & & \\
\hline Aquatic invertebrate & 0.03 & 1.34 & 8.38 & 0.06 & 1.69 \\
\hline Aeglidae & 0.03 & & 3.93 & & \\
\hline Bivalvia & & & 1.88 & & \\
\hline Gastropoda & & & 2.45 & & \\
\hline Microcrustacean & & & 0.13 & & 1.69 \\
\hline Porifera & & 1.34 & & & \\
\hline Testate amoebae & & & & 0.06 & \\
\hline \multicolumn{6}{|l|}{ UNDETERMINED } \\
\hline Detritus & 15.61 & 1.13 & 13.66 & 16.80 & 3.67 \\
\hline
\end{tabular}




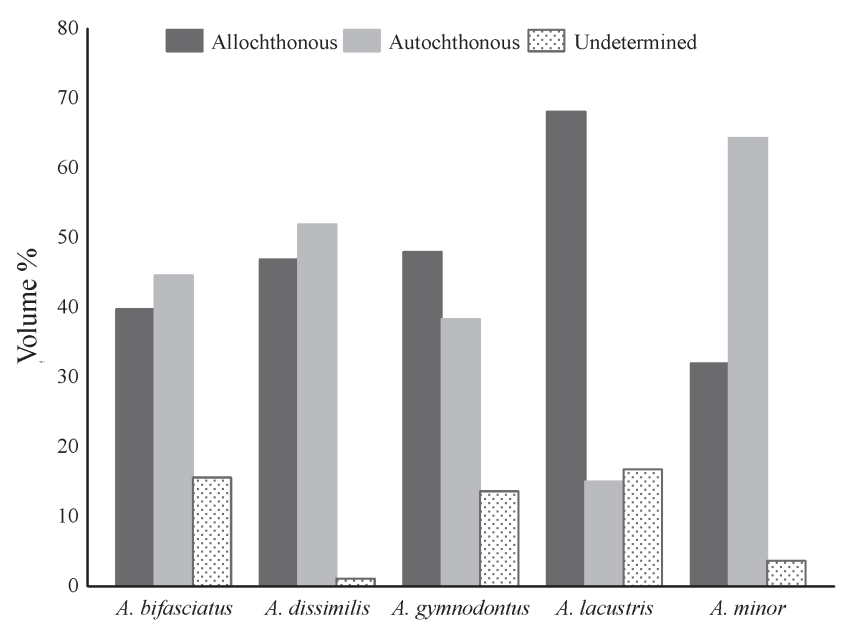

Fig. 2. Volumetric percentage of the origin of food items in the diet of Astyanax species in the Low Iguaçu River and tributaries in Brazil.
Astyanax gymnodontus and A. lacustris exhibited an omnivorous diet in which fruit/seed was the main resources, but the species complemented this with different foods (detritus, fish, and algae for the former and detritus and terrestrial insect for the latter; Tab. 1). The other species showed an herbivorous diet. Astyanax bifasciatus predominantly consumed terrestrial plant and algae. Astyanax dissimilis principally consumed algae and fruit/seed while A. minor mainly consumed algae (Tab. 1).

The PERMANOVA (pseudo- $F=12.73 ; p<0.01$ ) indicated differences among the diets of the species pairs, except for the pair A. dissimilis $\times A$. minor that showed similar diet preferences (pseudo- $t$ statistic; $p>0.05$ ) (Tab. 2). The observed dissimilarity, verified through SIMPER, indicated terrestrial plant and fruit/seed as the main food items that distinguished $A$. lacustris from the other species. In addition, the Rhodophyceae Compsopogon caeruleus was responsible for the dissimilarity in the diets of $A$. bifasciatus, A. dissimilis, A. gymnodontus, and A. minor (Tab. 2).

Tab. 2. Dissimilarity of Astyanax species diet in Lower Iguaçu River and its tributaries in Brazil as verified by SIMPER and PERMANOVA (pseudo-t). $\mathrm{Cc}=$ Compsopogon caeruleus; $\mathrm{Tp}=$ terrestrial plant; Fs=fruit/seed; $\mathrm{De}=\mathrm{detritus}$.

\begin{tabular}{|c|c|c|c|c|c|c|}
\hline \multirow[b]{2}{*}{ Species } & \multicolumn{5}{|l|}{ SIMPER Results } & \multirow{2}{*}{$\begin{array}{l}\text { PERMANOVA } \\
\text { Pair-wise Tests }\end{array}$} \\
\hline & Dissimilarity (\%) & Items & Contribution (\%) & Mean abundance $\mathrm{A}$ & Mean abundance B & \\
\hline \multirow{3}{*}{ A. bifasciatus $\times$ A. dissimilis } & \multirow{3}{*}{83.10} & $\mathrm{Cc}$ & 24.36 & 0.17 & 0.21 & \multirow{3}{*}{$t=1.92 ; p<0.01$} \\
\hline & & $\mathrm{Tp}$ & 21.59 & 0.22 & 0.11 & \\
\hline & & Fs & 10.22 & 0.05 & 0.08 & \\
\hline \multirow{3}{*}{ A. bifasciatus $\times$ A. gymnodontus } & \multirow{3}{*}{87.90} & $\mathrm{Tp}$ & 20.06 & 0.22 & 0.12 & \multirow{3}{*}{$t=4.04 ; p<0.01$} \\
\hline & & Fs & 16.85 & 0.05 & 0.20 & \\
\hline & & $\mathrm{Cc}$ & 14.61 & 0.17 & 0.06 & \\
\hline \multirow{3}{*}{ A. bifasciatus $\times$ A. lacustris } & \multirow{3}{*}{89.66} & Fs & 20.45 & 0.22 & 0.05 & \multirow{3}{*}{$t=5.41 ; p<0.01$} \\
\hline & & $\mathrm{Tp}$ & 19.66 & 0.06 & 0.22 & \\
\hline & & $\mathrm{Cc}$ & 14.25 & 0.02 & 0.17 & \\
\hline \multirow{3}{*}{ A. bifasciatus $\times A$. minor } & \multirow{3}{*}{82.93} & $\mathrm{Cc}$ & 24.71 & 0.17 & 0.21 & \multirow{3}{*}{$t=2.31 ; p<0.01$} \\
\hline & & $\mathrm{Tp}$ & 22.85 & 0.22 & 0.12 & \\
\hline & & De & 9.91 & 0.09 & 0.02 & \\
\hline \multirow{3}{*}{ A. dissimilis $\times$ A. gymnodontus } & \multirow{3}{*}{89.76} & $\mathrm{Cc}$ & 19.60 & 0.21 & 0.06 & \multirow{3}{*}{$t=2.87 ; p<0.01$} \\
\hline & & Fs & 17.99 & 0.08 & 0.20 & \\
\hline & & $\mathrm{Tp}$ & 14.18 & 0.11 & 0.12 & \\
\hline \multirow{3}{*}{ A. dissimilis $\times$ A. lacustris } & \multirow{3}{*}{89.94} & Fs & 21.92 & 0.22 & 0.08 & \multirow{3}{*}{$t=3.65 ; p<0.01$} \\
\hline & & $\mathrm{Cc}$ & 20.49 & 0.02 & 0.21 & \\
\hline & & $\mathrm{Tp}$ & 12.82 & 0.06 & 0.11 & \\
\hline \multirow{3}{*}{ A. dissimilis $\times$ A. minor } & \multirow{3}{*}{79.54} & $\mathrm{Cc}$ & 28.06 & 0.21 & 0.21 & \multirow{3}{*}{$t=0.97 ; p=0.4$} \\
\hline & & $\mathrm{Tp}$ & 17.40 & 0.11 & 0.12 & \\
\hline & & Fs & 11.80 & 0.08 & 0.05 & \\
\hline \multirow{3}{*}{ A. gymnodontus $\times$ A. lacustris } & \multirow{3}{*}{84.96} & Fs & 25.86 & 0.22 & 0.20 & \multirow{3}{*}{$t=1.88 ; p<0.01$} \\
\hline & & De & 16.03 & 0.09 & 0.12 & \\
\hline & & $\mathrm{Tp}$ & 13.18 & 0.06 & 0.12 & \\
\hline \multirow{3}{*}{ A. gymnodontus $\times A$. minor } & \multirow{3}{*}{89.64} & $\mathrm{Cc}$ & 19.33 & 0.06 & 0.21 & \multirow{3}{*}{$t=3.72 ; p<0.0$} \\
\hline & & Fs & 17.74 & 0.20 & 0.05 & \\
\hline & & $\mathrm{Tp}$ & 15.37 & 0.12 & 0.12 & \\
\hline & & Fs & 21.67 & 0.22 & 0.05 & \\
\hline A. lacustris $\times$ A. minor & 90.50 & $\mathrm{Cc}$ & 19.90 & 0.02 & 0.21 & $t=4.45 ; p<0.01$ \\
\hline & & $\mathrm{Tp}$ & 14.02 & 0.06 & 0.12 & \\
\hline
\end{tabular}


Astyanax species showed average centroid distance values above 0.6 (Tab. 1; Fig. 3), indicating a wide trophic niche breadth. Astyanax gymnodontus presented the largest niche (0.65) (Tab.1; Fig. 3) significantly different from that of other species (PERMDISP, $\mathrm{F}=3.78 p<0.01$ ) (Tab. 3).

The diet overlap was low for $55 \%$ of the Astyanax pairs, especially those composed of $A$. lacustris, as well as the pairs $A$. bifasciatus $\times A$. gymnodontus, $A$. gymnodontus $\times A$. minor, and A. dissimilis $\times A$. minor (Fig. 4).

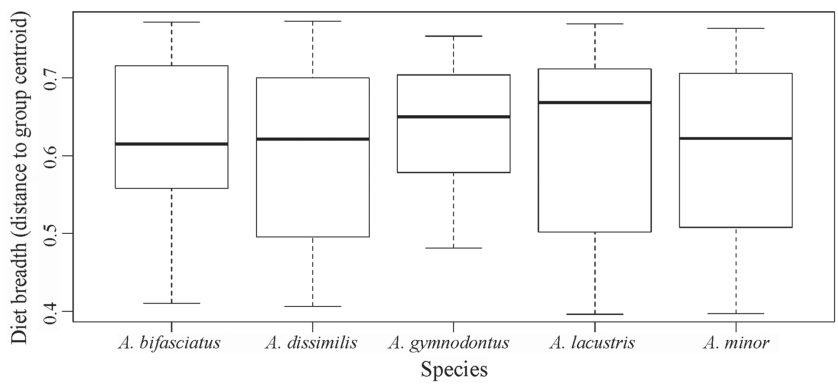

Fig. 3. Variation in diet breadth based on 40 food items consumed by five Astyanax species in the Low Iguaçu River and tributaries in Brazil. Diet breadth was evaluated by dispersion of the diet of species in the multivariate space by using PERMDISP (large spatial distance from the centroid indicates wide dispersion, i.e., wide trophic breadth). Lower and upper bars of the box represent 25 and 75 quartiles, respectively. The horizontal bar within each box represents the mean diet breadth.

Tab. 3. $P$-values of PERMDISP analyses of the diet breadth of five Astyanax species in the Low Iguaçu River and its tributaries in Brazil.

\begin{tabular}{lcccc}
\hline & A. dissimimilis & A. gymnodontus & A. lacustris & A. minor \\
\hline A. bifasciatus & 0.067 & $\mathbf{0 . 0 0 9}$ & 0.400 & 0.157 \\
A. dissimimilis & & $\mathbf{0 . 0 0 4}$ & 0.366 & 0.577 \\
A. gymnodontus & & & $\mathbf{0 . 0 0 3}$ & $\mathbf{0 . 0 0 2}$ \\
A. lacustris & & & & 0.688 \\
\hline
\end{tabular}

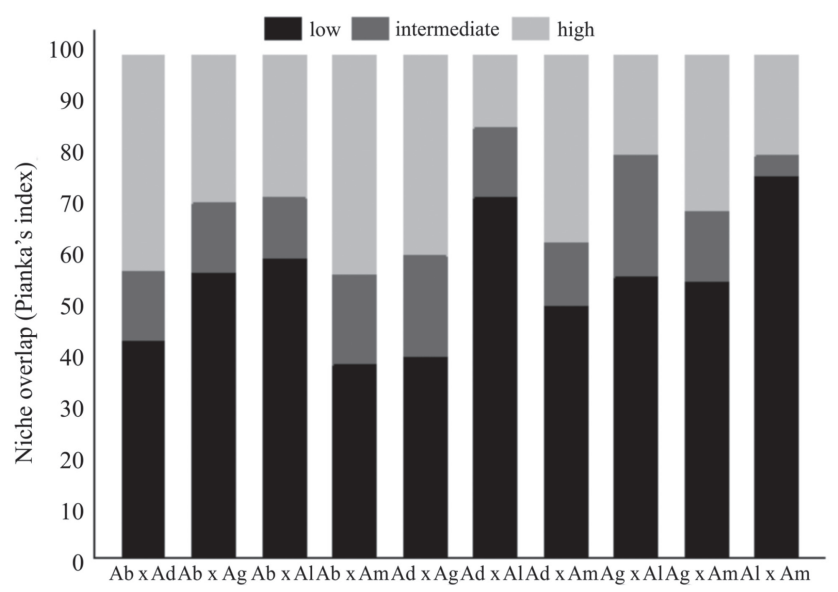

Fig. 4. Relative frequency (\%) of the diet overlap index of Astyanax species pairs in the Low Iguaçu River and tributaries in Brazil. $\mathrm{Ab}=A$. bifasciatus; $\mathrm{Ad}=A$. dissimilis; $\mathrm{Ag}=A$. gymnodontus $; \mathrm{Al}=A$. lacustris $; \mathrm{Am}=A$. minor. Low $<$ 0.39 ; intermediate $=0.40-0.59$; high $>0.60$.

\section{Discussion}

Our findings corroborated our prediction. Astyanax species consumed a variety of resources, exhibiting trophic segregation in co-occurrence. The observed consumption of foods of different trophic levels and origins (autochthonous and allochthonous) revealed a more generalist and opportunistic diet for A. gymnodontus and A. lacustris, while the other species had herbivorous dietary preferences. Astyanax is known for its opportunistic feeding habits (Lobón-Cerviá, Bennemann, 2000) and the use of different feeding strategies (Abelha et al., 2001, 2006; Mazzoni et al., 2010) that enable the species to forage at almost all trophic levels (Abelha et al., 2006). Most of the previous dietary information about Astyanax species from Iguaçu River is from pre- and post-impoundment studies in which the trophic plasticity of this fish group is revealed by their opportunistic feeding behavior in response to environmental changes (see Cassemiro et al., 2002, 2005; Loureiro-Crippa, Hahn, 2006; Delariva et al., 2013; Mise et al., 2013).

This peculiarity explains the wide array of food items of different origins (autochthonous and allochthonous) explored by the studied species and corroborates their wide trophic niche. The riparian forest in the sample sites, especially inside the Iguaçu National Park (almost pristine), may play an essential role in the abundance of these distinct food resources. This vegetation is a source of allochthonous food, such as terrestrial plant, fruit/seed and terrestrial insect, besides being a substrate represented by trunks, branches, and other structures that fall into the river bed and are colonized by algae and aquatic invertebrates, increasing the availability of autochthonous food resources to fish fauna.

The expressive consumption of fruit/seed and/ or terrestrial plant by A. bifasciatus, A. gymnodontus, and $A$. lacustris and algae by $A$. dissimilis and A. minor emphasized the preference toward foods of plant origin. Consistent with our results, most Astyanax species were previously described as herbivorous: A. bifasciatus, $A$. dissimilis (Delariva et al., 2013; Mise et al., 2013), and A. gymnodontus in the pre-impoundment period of Salto Caxias Reservoir (Cassemiro et al., 2005; Delariva et al., 2013) and A. lacustris (Cassemiro et al., 2002, 2005; Loureiro-Crippa, Hahn, 2006), whose preference for fruit/ seed was also reported by Andrian et al. (2001) and Silva et al. (2014). Additionally, A. minor was described as detritivorous in the Segredo Reservoir (Mise et al., 2013) and as herbivorous in lotic environments in the region of Salto Caxias Reservoir, showing a diet mainly composed of algae and plants (Delariva et al., 2013).

Although the species fed predominantly on terrestrial plant, fruit/seed and algae, the proportion of these main resources and those that were complementary (e.g., aquatic plant, terrestrial insect, detritus, and fish) varied among the different Astyanax species. These results highlight the ability of the species to differentiate their diets despite the usual tendency of Astyanax populations to adopt a generalist diet. 
The low values of food overlap may indicate trophic segregation among species (Corrêa et al., 2011). This is an expected result for similar species since the niche theory (Hutchinson, 1957) predicts that coexistence among species depends on a single difference or limiting similarity in order to minimize competition. Under these conditions, resource partitioning becomes an important mechanism for fish species segregation (Zaret, Rand, 1971; Edlund, Magnhagem, 1980), which is apparently operating among the populations of A. bifasciatus, $A$. gymnodontus, A. lacustris, A. dissimilis, and A. minor in the Low Iguaçu River. The similarity found in the diet of the pair $A$. minor $\times$ A. dissimilis was the only counterpoint to this result, but it does not discard ecological separation between these species since we investigated only one niche dimension. Usually congeneric species inhabiting the same area avoid competition through three possible ecological differences: they exploit different habitats or microhabitats, they consume different foods, or they are active at different times (Pianka, 2000). Another point to consider is that the similarity in the diet was mainly influenced by the high consumption of the alga Compsopogon caeruleus. Although the availability of food resources was not measured in the sampled sites, there must be high algal abundance in the sites owing to the rocky consistency of most of the sampled lotic stretches of the Iguaçu River and its tributaries, which may provide substrates for algal colonization, thus, reducing food limitations for $A$. minor $\times A$. dissimilis .

Despite the low values, the overlap of terrestrial plant, fruit/seed and Compsopogon caeruleus reinforced the importance of these food items in maintaining the studied Astyanax populations. This information gains relevance considering the landscape threats over the Iguaçu basin (Baumgartner et al., 2012; Kliemann et al., 2018 ), especially by dam construction and removal or degradation of the riparian vegetation. The loss of habitat heterogeneity in the conversion of lotic environments to reservoirs (Agostinho et al., 2007) and the limitation of allochthonous resources can be decisive for the interactions among species, with increasing competition and possible displacement of species with low fitness.

In conclusion, the wide range of food resources consumed by the evaluated Astyanax species demonstrates the potential of these species to exploit all environmental compartments. However, differences in the proportions and main resources consumed by each species indicate that trophic segregation promotes the co-occurrence of Astyanax species in the Low Iguaçu River.

\section{Acknowlegments}

We thank Consórcio Empreendedor Baixo Iguaçu (CEBI) for financial support and GETECH for providing logistical support for sampling and analyzing materials.

\section{References}

Abelha MCF, Agostinho AA, Goulart E. Plasticidade trófica em peixes de água doce. Acta Sci. 2001; 23(2):425-34. Available from: http://periodicos.uem.br/ojs/index.php/ActaSciBiolSci/ article/view/2696

Abelha MCF, Goulart E, Kashiwaqui EAL, Silva MR. Astyanax paranae Eigenmann, 1914 (Characiformes: Characidae) in the Alagados Reservoir, Paraná, Brazil: diet composition and variation. Neotrop Ichthyol. 2006; 4(3):349-56. http://dx.doi. org/10.1590/S1679-62252006000300006

Abell R, Thieme ML, Revenga C, Bryer M, Kottelat M, Bogutskaya $\mathrm{N}$ et al. Freshwater ecoregions of the world: a new map of biogeographic units for freshwater biodiversity conservation. BioScience. 2008; 58(1):403-14. https://doi.org/10.1641/B580507

Agostinho AA, Gomes LC, Pelicice FM. Ecologia e manejo de recursos pesqueiros em reservatórios do Brasil. Maringá: EDUEM; 2007.

Albert JS, Petry P, Reis RE. Major biogeographic and phylogenetic patterns. In: Albert JS, Reis RE, editors. Historical biogeography of Neotropical freshwater fishes. Berkeley and Los Angeles: University of California Press; 2011. p.21-58.

Anderson MJ. Distance-based tests for homogeneity of multivariate dispersions. Biometrics. 2006; 62(1):245-53. https://doi. org/10.1111/j.1541-0420.2005.00440.x

Andrian IF, Rodrigues HB, Peretti D. Dieta de Astyanax bimaculatus (Linnaeus, 1758) (Characiformes, Characidae) da área de influência do reservatório de Corumbá, Estado de Goiás, Brasil. Acta Sci. 2001; 23(2):435-40.

Barreto AP, Aranha JMR. Alimentação de quatro espécies de Characiformes de um riacho de Floresta Atlântica, Guaraqueçaba, Paraná, Brasil. Rev Bras Zool. 2006; 23(3):779-88. http://dx.doi. org/10.1590/S0101-81752006000300023

Baumgartner G, Pavanelli CS, Baumgartner D, Bifi AG, Debona T, Frana VA. Peixes do rio Iguaçu. Maringá: EDUEM; 2012.

Bicudo CEM, Bicudo RMT. Algas de águas continentais brasileiras: chave ilustrada para identificação de gêneros. São Paulo: Edusp; 1970.

Borror DJ, Delong DM. Introdução ao estudo dos insetos. São Paulo: Editora Edgar Blücher; 1988.

Buckup PA. The eastern Brazilian shield. In: Albert JS, Reis RE, editors. Historical biogeography of Neotropical freshwater fishes. Berkeley and Los Angeles: University of California Press; 2011. p.203-10.

Cassemiro FAS, Hahn NS, Delariva RL. Estrutura trófica da ictiofauna, ao longo do gradiente longitudinal do reservatório de Salto Caxias (rio Iguaçu, Paraná, Brasil), no terceiro ano após o represamento. Acta Sci. 2005; 27(1):63-71. http:// dx.doi.org/10.4025/actascibiolsci.v27i1.1362

Cassemiro FAS, Hahn NS, Fugi R. Avaliação temporal da dieta de Astyanax altiparanae (Pisces, Tetragonopterinae) durante o represamento do reservatório de Salto Caxias, PR. Acta Sci. 2002; 24(2):419-25.

Chesson P. Mechanisms of maintenance of species diversity. Annu Rev Ecol Evol Syst. 2000; 31:343-66. https://doi.org/10.1146/ annurev.ecolsys.31.1.343

Clarke KR. Non-parametric multivariate analyses of changes in community structure. Austral Ecol. 18(1):117-143. https://doi. org/10.1111/j.1442-9993.1993.tb00438.x

Clarke KR, Gorley RN. Primer v6: User Manual/Tutorial. Plymouth: PRIMER-E; 2006.

Corrêa CE, Albrecht MP, Hahn NS. Patterns of niche breadth and feeding overlap of the fish fauna in the seasonal Brazilian Pantanal, Cuiabá River basin. Neotrop Ichthyol. 2011; 9(3):63746. http://dx.doi.org/10.1590/S1679-62252011000300017 
Cox CB, Moore PD, Ladle RJ. Biogeography: an ecological and evolutionary approach. New York: Halsted Press; 1980.

Dalla Corte AP, Hentz AMK, Doubrawa B, Sanquetta CR. Environmental fragility of Iguaçu river watershed, Paraná, Brazil. Bosque (Valdivia). 2015; 36(2):287-97. http://dx.doi. org/10.4067/S0717-92002015000200014

Delariva RL, Hahn NS, Kashiwaqui EAL. Diet and trophic structure of the fish fauna in a subtropical ecosystem: impoundment effects. Neotrop Ichthyol. 2013; 11(4):891-904. http://dx.doi. org/10.1590/S1679-62252013000400017

Edlund AM, Magnhagen C. Food segregation and consumption suppression in two coexisting fishes, Pomatoschistus minutus and P. microps: an experimental demonstration of competition. Oikos. 1980; 36(1):23-27. http://dx.doi.org/10.2307/3544374

Garavello JC, Sampaio FAA. Five new species of genus Astyanax Baird \& Girard, 1854 from rio Iguaçu, Paraná, Brazil (Ostariophysi, Characiformes, Characidae). Braz J Biol. 2010; 70(3):847-65. http://dx.doi.org/10.1590/S151969842010000400016

Gotelli NJ, Entsminger GL. EcoSim: null models software for ecology. (Version 7) [Computer software manual - Internet]. Acquired Intelligence Inc. \& Kesey-Bear; 2010.

Grossman GD. Food resources partitioning in a rocky intertidal fish assemblage. J Zool. 1986; 1(2):317-55. https://doi. org/10.1111/j.1096-3642.1986.tb00642.x

Hellawel JM, Abel R. A rapid volumetric method for the analysis of the food of fishes. J Fish Biol. 1971; 3(1):29-37. https://doi. org/10.1111/j.1095-8649.1971.tb05903.x

Hutchinson GE. Concluding remarks. Cold Spring Harb Symp Quant Biol.1957; 22:415-27. https://doi.org/10.1101/ SQB.1957.022.01.039

Hyslop EJ. Stomach contents analysis - a review of methods and their application. J Fish Biol. 1980; 17(4):411-29. https://doi. org/10.1111/j.1095-8649.1980.tb02775.x

Juncos R, Milano D, Macchi PJ, Vigliano PH. Niche segregation facilitates coexistence between native and introduced fishes in a deep Patagonian lake. Hydrobiologia. 2015; 747(1):53-67. https://doi.org/10.1007/s10750-014-2122-z

Kliemann BCK, Delariva RL, Amorim JPA, Ribeiro CS, Silva B, Silveira RV, Ramos IP. Dietary changes and histophysiological responses of a wild fish (Geophagus cf. proximus) under the influence of tilapia cage farm. Fish Res. 2018; 204:337-47. https://doi.org/10.1016/j.fishres.2018.03.011

Kylafis G, Loreau M. Niche construction in the light of niche theory. Ecol Lett. 2011; 14(2):82-90. https://doi.org/10.1111/j.14610248.2010.01551.x

Lobón-Cerviá J, Bennemann S. Temporal trophic shifts and feeding diversity in two sympatric, neotropical, omnivorous fishes: Astyanax bimaculatus and Pimelodus maculatus in Rio Tibagi (Paraná, Southern Brazil). Arch Hydrobiol. 2000; 149(2):285306. http://dx.doi.org/10.1127/archiv-hydrobiol/149/2000/285

Loureiro-Crippa VE, Hahn NS. Use of food resources by the fish fauna of a small reservoir (rio Jordão, Brazil) before and shortly after its filling. Neotrop Ichthyol. 2006; 4(3):357-62. http:// dx.doi.org/10.1590/S1679-62252006000300007

Maack R. Geografia Física do Estado do Paraná. Curitiba: Ed. José Olympio; 1981.

Mazzoni R, Moraes M, Rezende CF, Miranda JC. Alimentação e padrões ecomorfológicos das espécies de peixes de riacho do alto rio Tocantins, Goiás, Brasil. Iheringia Ser Zool. 2010; 100(2):162-68. http://dx.doi.org/10.1590/S007347212010000200012

McCafferty WP. Aquatic entomology: the fishermen's and ecologist's illustrated guide to insects and their relatives. Boston: Jones an Barlett; 1981.
Mise FT, Fugi R, Pagotto JPA, Goulart E. The coexistence of endemic species of Astyanax (Teleostei: Characidae) is propitiated by ecomorphological and trophic variations. Biota Neotrop. 2013; 13(3):21-28. http://dx.doi.org/10.1590/S167606032013000300001

Mugnai R, Nessimian JL, Baptista DF. Manual de identificação de macroinvertebrados aquáticos do Estado do Rio de Janeiro. Rio de Janeiro: Technical Books; 2010.

Neves MP, Silva JC, Baumgartner D, Baumgartner G, Delariva RL. Is resource partitioning the key? The role of intra-interspecific variation in coexistence among five small endemic fish species (Characidae) in subtropical rivers. J Fish Biol. 2018; 93(2):23849. https://doi.org/10.1111/jfb.13662

Novakowski GC, Hahn NS, Fugi R. Diet seasonality and food overlap of the fish assemblage in a pantanal pond. Neotrop Ichthyol. 2008; 6(4):567-76. http://dx.doi.org/10.1590/S167962252008000400004

Oksanen J, Blanchet FG, Friendly M, Kindt R, Legendre P, McGlinn D, O’Hara B, Simpson GL, Solymos P, Stevens MHH, Szoecs E, Wagner H. Package 'vegan'. Community Ecology Package [Computer software manual - Internet]. R package version 2.4-2; 2009. Available from: http://CRAN.R-project.org/package=vegan

Pavanelli CS, Oliveira AM. A redescription of Astyanax gymnodontus (Eigenmann, 1911), new combination, a polymorphic characid fish from the rio Iguaçu basin, Brazil. Neotrop Ichthyol. 2009; 7(4):56978. https://dx.doi.org/10.1590/S1679-62252009000400003

Pianka ER. The structure of lizard communities. Annu Rev Ecol Evol Syst. 1973; 4(1):53-74.

Pianka ER. Evolutionary ecology. San Francisco: Benjamin/ Cummings; 2000.

R Development Core Team. R: a language and environment for statistical computing [Computer software manual - Internet]. Vienna: R Foundation for Statistical Computing; 2017. Available from: https://www.r-project.org/

Ricklefs RE, Schluter D. Species diversity: regional and historical influences. In: Ricklefs RE, Schluter D, editors. Species diversity in ecological communities: historical and geographical perspectives. Chicago: The University of Chicago Press; 1993. p.350-63.

Ross ST. Resource partitioning in fish assemblages: a review of field studies. Copeia. 1986; 1986(2):352-88. https://dx.doi. org/10.2307/1444996

Schoener TW. Resource partitioning in ecological communities. Science.1974; 185(4145):27-39. https://doi.org/10.1126/ science.185.4145.27

Silva JC, Gubiani EA, Delariva RL. Use of food resources by small fish species in Neotropical rivers: responses to spatial and temporal variations. Zoologia (Curitiba). 2014; 31(5):435-44. http://dx.doi. org/10.1590/S1984-46702014000500004

Wang M, Liu F, Lin P, Yang S, Liu H. Evolutionary dynamics of ecological niche in three Rhinogobio fishes from the upper Yangtze River inferred from morphological traits. Ecol Evol. 2015; 5(3):567-77. https://doi.org/10.1002/ece3.1386

Wiens JJ, Ackerly DD, Allen AP, Anacker BL, Buckley LB, Cornell $\mathrm{HV}$ et al. Niche conservatism as an emergin principle in ecology and conservation biology. Ecol Lett. 2010; 13(10):1310-24. https://doi.org/10.1111/j.1461-0248.2010.01515.x

Zaret TM, Rand AS. Competition in tropical stream fishes: support for the competitive exclusion principle. Ecology. 1971; 52(2):336-42. https://doi.org/10.2307/1934593

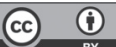

Submitted March 25, 2019 Accepted October 2, 2019 by Rosemara Fugi 